\title{
CROSS-BORDER LOSS OFFSET AND FORMULARY APPORTIONMENT: \\ HOW DO THEY AFFECT MULTIJURISDICTIONAL FIRM INVESTMENT SPENDING AND INTERJURISDICTIONAL TAX COMPETITION?
}

\author{
MARCEL GÉRARD \\ JOANN M. WEINER \\ CESIFO WORKING PAPER NO. 1004 \\ CATEGORY 1: PUBLIC FINANCE \\ August 2003
}

Presented at CESifo Area Conference on Public Sector Economics, May 2003

An electronic version of the paper may be downloaded

- from the SSRN website: $\quad$ www.SSRN.com

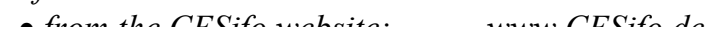




\title{
CROSS-BORDER LOSS OFFSET AND FORMULARY APPORTIONMENT: HOW DO THEY AFFECT MULTIJURISDICTIONAL FIRM INVESTMENT SPENDING AND INTERJURISDICTIONAL TAX COMPETITION?
}

\begin{abstract}
Motivated by the EU Commission's suggested company tax reforms, this paper investigates how cross-border loss offset and formulary apportionment of a consolidated tax base affect the investment and transfer pricing behaviour of a multijurisdictional firm, and how they affect the behaviour of governments potentially engaged in tax competition. The paper shows that cross-border loss offset mitigates both the reactions of a multijurisdictional firm to tax changes and the amount of tax competition engaged in by governments. However, formulary apportionment (with a consolidated tax base) boosts the sensitivity of firms to tax changes and increases the scope for interjurisdictional tax competition as well. For governments, formulary apportionment operates like a risk-sharing or partial equalisation mechanism.
\end{abstract}

JEL Code: H31, H73, H87.

Keywords: cross border loss offset, multinational firms, tax competition.

\author{
Marcel Gérard \\ Catholic Universities of Mons (Fucam) \\ Chaussée de Binche 151 \\ B-7000 Mons \\ Belgium \\ gerard@fucam.ac.be
}

\author{
Joann Martens Weiner \\ Saint-Louis University (Fusl) \\ Brussels \\ Belgium \\ weiner5@attglobal.net
}

Authors are indebted to Louis Eeckhoudt, Harry Grubert, Nicolas Marceau, Michael Smart, Peter Birch Sorensen and John Wilson for valuable comments and suggestions. However any errors remain ours. Earlier versions of that paper have been selected for presentation at various conferences in 2003, including PET03 in Durham, the IIPF congress in Prague and the NTA meeting in Chicago. 


\section{Introduction}

In late 2001, the EU Commission proposed a new approach for taxing multinational companies operating within the European Union. ${ }^{1}$ That approach has two main characteristics. First, each multinational company should be able to compute a single consolidated tax base under a single set of tax rules for its EU-wide operations. Second, that consolidated tax base should then be apportioned among the various EU member states according to an agreed mechanism for taxation at local rates. ${ }^{2}$ In presenting this new approach, the Commission explained that allowing EU-wide consolidation with an agreed cross-country distribution of profits would help remove the existing tax obstacles to the conduct of EU-wide activities.

The suggested reform has several advantages: tax-based distinctions between branches and subsidiaries would disappear; cross-border mergers would not incur adverse tax consequences; to a great extent, arm's length transfer pricing and cost allocation between members of the group located in different member states would no longer be necessary for tax purposes; and, most importantly, cross-border loss offset would occur. ${ }^{3}$ This latter option appears to be particularly attractive to some EU businesses. ${ }^{4}$ Thus, in many respects, consolidated base taxation with formula apportionment may be an EU multinational taxpayer's dream come true, as it appears to solve all of these issues at once.

The propositions of the EU Commission have been analysed on various respects by several authors. See, for example, the collection of papers presented in CESIfo Forum, European Taxation, and Ifo-Studiën. ${ }^{5}$ Weiner $(2001 b, 2002 a)$ and Gérard $(2002,2003)$ have separately examined these proposals, which are described in section 2. This joint paper builds on their earlier work to investigate the impact of cross border loss offset within a formulary

\footnotetext{
${ }^{1}$ See European Commission $(2001,2002)$

${ }^{2}$ A formula would not be required if all of the revenue collected from the corporate income tax accrued to the European Union, an option that is not under serious consideration. In all other cases, the consolidated tax base would be distributed to the member states for taxation at the local rate using a formula. While the details of the four options vary, apart from the exception just noted, all of the options use a formula to apportion the tax base to the member states.

${ }^{3}$ The extent to which these advantages arise depends on the definition of the EU taxable corporate group and the treatment of income and activities outside of the EU.

${ }^{4}$ The Commission's Study (2002, p. 327) presents an example provided by UNICE, the federation of European employers, where one of its companies would have saved ECU 320 million if it had been able to use its losses of ECU 880 million in some member states to offset profits of ECU 870 million in other member states. For additional details, see Union of Industrial and Employers' Confederations of Europe (2000).

${ }^{5}$ CESIfo Forum, 2001, vol. 1, European Taxation, 2002, vol. 42 (8), Ifo-Studiën, 2002, vol. 48 (4),
} 
apportionment system. The Commission, in presenting its analysis, noted that it had not analyzed these features in depth. Moreover, while Gérard (2002) recognised that cross-border loss offsetting could make consolidation with apportionment superior to taxation under the separate-entity approach, he did not address this issue analytically.

In section 3, we consider the impact of cross-border loss offsetting in the framework of corporate tax systems operated under a separate-entity approach. We first examine the impact on investment, sales, and transfer pricing under the source principle for international taxation, and then repeat the analysis for the alternative residence principle for international taxation.

In section 4, we substitute the separate-entity approach with a consolidated tax base and a formulary apportionment mechanism. We are aware that, as pointed out by Weiner (1999, 2001a), defining an appropriate and acceptable apportionment mechanism presents significant technical and political difficulties. ${ }^{6}$ As implementing formulary apportionment would be a departure from the system of separate accounting with arm's length pricing currently incorporated in EU company tax systems, such a move raises complicated tax policy matters. Critics have suggested that the system might even conflict with the principles underlying international tax rules and treaties. Finally, although it eliminates some distortions, formula apportionment introduces new distortions to cross-border business activity. As a result, implementation of a consolidated tax base with formula apportionment may appear to be the EU's worst nightmare.

Section 5 suggests some conclusions.

From a methodological point of view, we nest the issue of cross-border loss offset in a setting where the multinational company faces an uncertain return on investment. More precisely we consider that such a firm distributes its investment and sales activities between two jurisdictions, a high tax and a low tax jurisdiction, and that two states of the nature may occur in either jurisdiction, a good state where profit is positive and a bad state where a loss occurs. This loss may, or may not, be totally or only partially offset against any profit earned in the other jurisdiction. We will examine, in particular, if the move from no loss offset to a partial

\footnotetext{
${ }^{6}$ We use the term apportionment to refer to the process of distributing the tax base across jurisdictions using a formula and use the term allocation to refer to the process of assigning specific items of income to a particular jurisdiction. Some authors use the terms apportionment and allocation interchangeably.
} 
or total loss offset system changes the strategy of the firm in terms of the location of plants, of the location of distribution centres and of transfer pricing choices.

We will also investigate the impact of cross-border loss offsetting and formulary apportionment on interjurisdictional tax competition.

Our contribution relates to the economic literature at the junction of public finance and uncertainty; that literature, as pointed out among others by Myles (1995) textbook, which includes Mossin (1968), Stiglitz (1969), Diamond and Stiglitz (1974), Sandmo (1977) and Fucam colleagues Eeckhoudt and Hansen (1982). More recently Eeckhoudt, Gollier and Schlesinger (1997) specifically cope with the no loss offset provision and the attitude towards risk of a risk-neutral firm. However those works examine loss offset over time rather than at a given moment of time and not across affiliates of a same group, as we do in this paper.

In addition to tax considerations, the conclusions from our examination of cross-border loss offset can be generalised to situations where the risk associated with an activity in one jurisdiction can be matched against the return of another activity in another jurisdiction. This situation allows governments to achieve a certain risk-sharing potential for their revenue from corporate income taxation.

\section{The EU Commission's proposed approaches}

The EU Commission Study (2002) presents four approaches that may achieve its long-term goal: Home State Taxation (HST), Common (Consolidated) Base Taxation (CCBT), a European Union Corporate Income Tax (EUCIT) and a compulsory harmonized EU tax base. Except for a variation of EUCIT where the revenue from the company tax accrues to the Commission, each method also uses a formula to allocate the tax base to the member states. ${ }^{7}$ While all methods require adopting a formula to implement a comprehensive solution, the implications of adopting a formula have not been analysed in-depth for any of the methods. To a great extent, the debate has centred on which of the four proposals is more feasible in political terms, rather than on which proposal is more practical in economic terms. Following the company tax conference held in April 2002, the Commission has decided to restrict its 
analysis to the first two options. ${ }^{8}$ The Commission is now proceeding on a two-track approach. It is examining the potential use of Home State taxation for Small- and MediumSized Enterprises within a limited number of Member States and examining the potential of using International Accounting Standards as a potential starting point for the EU common consolidated tax base. ${ }^{9}$

Table 1 summarizes the approaches for obtaining consolidated taxation in the European Union. ${ }^{10}$ Table 2 summarizes the separate accounting and formula apportionment methods. Separate accounting and formula apportionment are two different ways to determine the amount of a company's income attributable to a jurisdiction. ${ }^{11}$

\footnotetext{
${ }^{7}$ For an analysis of the various approaches, see Westberg (2002).

${ }^{8}$ For a review of this conference, see Weiner (2002b).

${ }^{9}$ See Commission (2003).

${ }^{10}$ Source for descriptions: Part IV. Chapter 13 "Options for comprehensive approaches to EU company taxation," in Company Taxation in the Internal Market, European Commission (2002).

${ }^{11}$ There is a wide body of literature analysing the strengths and weaknesses of both separate accounting and formula apportionment. See McDaniel (1994), Hellerstein (1993), Musgrave (2000), among others.
} 


\section{Table 1 - Alternative systems proposed by the EU Commission}

\section{Home state taxation}

Under Home State Taxation, companies would have the option of computing their income for their operations located in various Member States participating in the home state tax system according to the company income tax rules of the Member State where their headquarters are located (the "home" state). The tax authorities of the home state would administer their particular home state tax system. All groups in the home State area would share their net profit according to the same formula, but the method for offsetting profits and losses would vary according to the rules in the home State. Post-apportionment profits would be taxed at local rates.

\section{Common consolidated base taxation}

Under Common Consolidated Base Taxation, all or a group of Member States would agree on a set of common rules for establishing the taxable base. Companies would then have the option of calculating their income according to the rules for the new common EU tax base. This EU tax base would operate in parallel with existing national rules. The Member State where the company was headquartered would administer the common EU tax base. All groups choosing this method would share their net profit according to the same formula, and the method for offsetting profits and losses would be identical. Post-apportionment profits would be taxed at local rates.

\section{European Union company income tax}

Under a European Union Company Income Tax, a new EU tax base would be developed and would operate in parallel with existing national rules. It would be optional for companies. In one form, it would be administered by a new tax authority, with a single EU tax rate, with revenues funding EU institutions and activities and any excess allocated to the Member States according to an agreed formula. In another form, individual Member States could administer the EU company income tax and apply its own tax rate to its allocated share of the tax base.

\section{Compulsory harmonised tax base}

Under this approach, a single EU tax base and tax code would replace national company tax systems. This EU tax system would apply to all enterprises in all Member States. Member States would administer the tax so there would be no need to create a centralized tax authority. Consolidated profits would be apportioned to the Member States according to the terms of an agreed mechanism, where they would be taxed at local rates. 
$\underline{\text { Table } 2 \text { - Separate accounting vs formula apportionment }}$

\section{Separate accounting}

Under this system, companies apply traditional accounting methods to calculate the income earned by the legally separate entities located in different jurisdictions, treating transactions with affiliated entities as if they had occurred with independent entities. For tax purposes, corporate entities are required to price internal transactions with their related entities at the level that would have prevailed had these transactions occurred with unrelated parties. These market-based, or arm's length prices, are those that approximate the prices that independent entities would use when selling goods and services to each other in a market relationship. When operations are located in different countries, this process identifies the amount of profit attributable to each country where the multinational company does business.

\section{Formula apportionment}

Under formula apportionment, companies do not attempt to separate the income of an affiliated corporate group along geographic lines. Instead, under apportionment, a corporate group first calculates its net income for the entire group and then apportions that income to each location where it does business using a formula. Formula apportionment as traditionally used does not necessarily attempt to identify the geographic source of a company's profits. Instead, apportionment provides a rough approximation of the amount of income generated from the company's activity in each location where it does business. The formula used to apportion a multistate company's income typically includes factors that relate to that activity, e.g., property, payroll, and gross receipts (sales). The U.S. states have used the apportionment system for nearly a century, and the Canadian provinces have used the system for more than a half a century. Under the U.S. state apportionment method, a company doing business in several states would use federal taxable income as its total income and, after making certain adjustments, apportion that income to each state using a formula based on location of its business activity in the various states. ${ }^{12}$ Under the Canadian method, the federal government calculates the tax liability for each province that participates in certain federal collection agreements. The federal government then allocates each province its share of federal income according to a two-factor payroll and sales formula. The three provinces that do not participate in the collection agreements use the same formula and generally the same tax base.

\section{Cross border loss offset under separate accounting taxation}

As in Gérard (2002), we assume a multijurisdictional firm which consists of a parent and two affiliated entities, such as factories or stores. These entities are either separately incorporated - they are then subsidiaries of the parent - or they are not - they are then branches of the

\footnotetext{
${ }^{12}$ These adjustments include eliminating income that states are constitutionally prohibited from taxing and adjusting for differences between state and federal tax law.
} 
parent. ${ }^{13}$ The affiliated entities are located in two different jurisdictions denoted by $i$ and $j$ while the parent is located in a jurisdiction denoted as $r$, a jurisdiction which can be either $i$ or $j$. Without loss of generality the parent can be either a company or an individual (i.e., a "person"), although in the logic of the analysis of cross-border loss offsetting, it has to be a company. The company is deemed to have continuity of life.

In terms of the model specifications, the multijurisdictional firm has invested one unit of money in production tools which are distributed among the affiliates. A fraction $\alpha$ has been invested in the entity located in jurisdiction $i$ and a fraction $1-\alpha$ in the entity located in jurisdiction $j$. Together the two entities produce and sell one unit of good per period. Entity $i$ produces a fraction $\alpha$ and entity $j$ produces $1-\alpha$. Entity $i$ sells a fraction $q$ of the total production on the retail market while entity $j$ sells $1-q$. The excess production $q-\alpha$ of entity $j$ is sold by entity $j$ to entity $i$ at an internal transfer price of $p$.

Adopting an intertemporal perspective ${ }^{14}$ we define $c, p$, and $v$, as the discounted flows of unit production costs, internal transfer prices, and unit retail prices, respectively, with $c \leq p \leq v{ }^{15}$ Except for the transfer price, which the firm sets, those variables are exogenously determined. To allow us to analyse loss offsetting in a tractable way, we assume that, apart from manipulating transfer prices, dividends are the only means to channel funds from the affiliates to the parent entity ${ }^{16}$. Costs are incurred even if the production is not sold.

We suppose that entity $i$ sells its output $q$ with probability $\omega$ while it sells none of its output with probability $1-\omega$; the same probabilities hold for the entity located in jurisdiction $j .{ }^{17}$ As a consequence the value of the project before tax can obey four different expressions depending

\footnotetext{
${ }^{13}$ The distinction between operating as a subsidiary or as a branch generally has no economic substance. However, as a subsidiary has a separate legal personality while a branch has no such separate identify, multijurisdictional companies may often prefer to organize a new operation as a branch, in which case loss offsetting automatically occurs, and then convert the branch to a separate entity once it become profitable. Providing cross-border loss-offsetting would eliminate the need for companies to undertake such actions simply for the purpose of using the losses. Some firms, such as those in financial services, operate in branch form for legal reasons.

${ }^{14}$ We keep intertemporality as simple as possible in this paper to avoid technical difficulties that could distract from the core issue; on the intertemporality issue see Myles (1995) and typical intertemporal approaches, such as Auerbach (1979) and Bradford (1981).

${ }^{15}$ We introduce tax elements affecting the various sources of funds directly in the equations so that we can use a discount rate independent of the tax rates.

${ }_{16}$ The firm is equity funded, meaning we can abstract from the issue of debt finance. See Gerard (2002) for an alternative specification.
} 
on which state of the nature occurs. These four possible outcomes, for jurisdiction $i$ and $j$, respectively, are shown below:

(i) good - good, probability $\omega^{2}$

$$
\begin{aligned}
V^{g g} & =[v q-p(q-\alpha)-c \alpha]+[v(1-q)+p(q-\alpha)-c(1-\alpha)]-1 \\
& =v-c-1
\end{aligned}
$$

(ii) $\operatorname{good}-$ bad, probability $\omega(1-\omega)$

$$
\begin{aligned}
V^{g b} & =[v q-p(q-\alpha)-c \alpha]+[p(q-\alpha)-c(1-\alpha)]-1 \\
& =v q-c-1
\end{aligned}
$$

(iii) bad - good, probability $(1-\omega) \omega$

$$
\begin{aligned}
V^{b g} & =[-p(q-\alpha)-c \alpha]+[v(1-q)+p(q-\alpha)-c(1-\alpha)]-1 \\
& =v(1-q)-c-1
\end{aligned}
$$

(iv) bad - bad, probability $(1-\omega)^{2}$

$$
\begin{aligned}
V^{b b} & =[-p(q-\alpha)-c \alpha]+[p(q-\alpha)-c(1-\alpha)]-1 \\
& =-c-1
\end{aligned}
$$

Then, the expected value of the firm, again before tax, is

$$
E\left(V^{B T}\right)=\omega v-c-1
$$

assumed to be positive, otherwise the firm will not participate. We immediately see that this expression is independent of $\alpha$ so that, in the absence of tax, there is no incentive to locate in either jurisdiction.

\subsection{Taxation under pure source vs. pure residence taxation with no loss offset}

Let us now introduce taxation. Consider first the case of no cross border loss offset and that tax is levied at the level of the active entities (pure source taxation) rather than at the parent level (residence taxation); the tax base is also characterised by depreciation allowances: one unit of investment in jurisdiction $i$ creates a flow of $a_{i}$ of tax shield. The corporate tax rate in $i$ is denoted $\tau_{i}$. Symmetric design applies for the other jurisdiction.

\footnotetext{
${ }^{17}$ Assuming that sales is the only source of uncertainty does not restrict the core message of the investigation; on
} 
The tax liabilities $(T)$ in jurisdiction $i$ are then either

$$
T_{i}=\tau_{i}\left[v q-p(q-\alpha)-\left(c+a_{i}\right) \alpha\right]
$$

if the firm has positive sales with probability $\omega$, or

$$
T_{i}=0
$$

if the firm has no sales with probability $1-\omega$.

The expected tax liability for the entire multinational enterprise is then,

$$
\begin{aligned}
E\left(T^{N L O}\right) & =\omega \tau_{i}\left[v q-p(q-\alpha)-\left(c+a_{i}\right) \alpha\right] \\
& +\omega \tau_{j}\left[v(1-q)+p(q-\alpha)-\left(c+a_{j}\right)(1-\alpha)\right]
\end{aligned}
$$

The expected after-tax value of the firm under source taxation and with no loss offsetting,

$$
E\left(V^{N L O}\right)=E\left(V^{B T}\right)-E\left(T^{N L O}\right)
$$

now depends on the distribution of investment, $\alpha$, between the active entities, and on the distribution of the sales centres, $q$, as well. Moreover, as long as tax rates are not identical in the two jurisdictions, there is room for strategic transfer pricing within the firm. Indeed, assuming that the firm changes only one instrument at a time, we can see how the expected after-tax value of the firm is affected by changes in the location of investment and sales, and in the internal transfer price, respectively:

$$
\begin{gathered}
\frac{d E\left(V^{N L O}\right)}{d \alpha}=-\omega\left(\tau_{i}-\tau_{j}\right)(p-c)+\omega\left(\tau_{i} a_{i}-\tau_{j} a_{j}\right) \\
\frac{d E\left(V^{N L O}\right)}{d q}=-\omega\left(\tau_{i}-\tau_{j}\right)(v-p)
\end{gathered}
$$

and

$$
\frac{d E\left(V^{N L O}\right)}{d p}=\omega\left(\tau_{i}-\tau_{j}\right)(q-\alpha)
$$

Capital export tax neutrality exists in such a setting only if the right hand side of the last three equations vanishes. A sufficient condition to reach capital export neutrality, therefore, is that tax rates and tax bases are harmonized, i.e., that $\tau_{i}=\tau_{j}$ and $a_{i}=a_{j}$.

Similarly the transfer pricing issue disappears if $\tau_{i}=\tau_{j}$. 
If, by contrast, the tax is levied at the level of the parent entity (pure residence taxation), then the tax system would be capital export neutral. In a system of pure residence taxation, the location of the parent is important, unless tax rates and tax bases are independent of that location. This condition, again, implies that both tax rates and tax bases are harmonized.

To see this case, note that equation (8) would become

$$
E\left(T^{N L O}\right)=\omega \tau_{r}\left[v-c-a_{r}\right]
$$

so that its value depends on the location of the parent company except when $\tau_{r}, a_{r}=\tau, a \forall r$. However, although the location of the parent is not independent of local taxes, with pure residence taxation the location of the parent is now independent of the distribution of the investment and the sales centres and of the transfer price as well.

\subsection{Cross border loss offset}

Let us now introduce cross border loss offset. To do so, we set a dummy variable $k$ which equals zero if cross border loss offset is not permitted, and which equals one if such loss offsetting is allowed. ${ }^{18}$ With cross-border loss offsetting, the expected tax liability of the firm, $E(T)$, as shown earlier in equation (8) without loss offsetting becomes, under taxation at source,

$$
\begin{aligned}
E\left(T^{L O}\right)= & \omega^{2} \tau_{i}\left[v q-p(q-\alpha)-\left(c+a_{i}\right) \alpha\right] \\
& +\omega^{2} \tau_{j}\left[v(1-q)+p(q-\alpha)-\left(c+a_{j}\right)(1-\alpha)\right] \\
& +k \omega(1-\omega) \tau_{i}\left[v q-p(q-\alpha)-\left(c+a_{i}\right) \alpha+p(q-\alpha)-\left(c+a_{j}\right)(1-\alpha)\right] \\
& +k(1-\omega) \omega \tau_{j}\left[v(1-q)+p(q-\alpha)-\left(c+a_{j}\right)(1-\alpha)-p(q-\alpha)-\left(c+a_{i}\right) \alpha\right]
\end{aligned}
$$

which can be rewritten,

$$
\begin{aligned}
E\left(T^{L O}\right)= & E\left(T^{N L O}\right) \\
& +k \omega(1-\omega)\left[\left(\tau_{i}-\tau_{j}\right) p(q-\alpha)-\tau_{i}\left(c+a_{j}\right)(1-\alpha)-\tau_{j}\left(c+a_{i}\right) \alpha\right]
\end{aligned}
$$

\footnotetext{
${ }^{18}$ Alternatively $k$ can be viewed as a value between zero and one, a value other than zero or one corresponding to a partial loss offset. Also we assume that the tax base in one jurisdiction is large enough to absorb losses in the other jurisdiction; relaxing that assumption implies using a more complicated formalisation but does not change the lesson of the model.
} 
so that, under the assumption that changing the rules regarding cross border loss offset does not necessarily alter the tax rates, expected tax liabilities are not larger when losses can be offset across borders, or ${ }^{19}$

$$
E\left(T^{L O}\right) \leq E\left(T^{N L O}\right)
$$

Equations (9) to (11) become, assuming again that the firm modifies only one instrument at a time,

$$
\begin{gathered}
\frac{d E\left(V^{L O}\right)}{d \alpha}=\frac{d E\left(V^{N L O}\right)}{d \alpha}+k \omega(1-\omega)\left[\left(\tau_{i}-\tau_{j}\right)(p-c)-\left(\tau_{i} a_{j}-\tau_{j} a_{i}\right)\right] \\
\frac{d E\left(V^{L O}\right)}{d q}=\frac{d E\left(V^{N L O}\right)}{d q}-k \omega(1-\omega)\left(\tau_{i}-\tau_{j}\right) p
\end{gathered}
$$

and

$$
\frac{d E\left(V^{L O}\right)}{d p}=\frac{d E\left(V^{N L O}\right)}{d p}-k \omega(1-\omega)\left(\tau_{i}-\tau_{j}\right)(q-\alpha)
$$

and the same sufficient conditions for capital export neutrality hold, i.e., tax rates and tax bases are identical. Similar results hold again for transfer pricing.

The question however is what happens when the necessary conditions for capital export neutrality are not a priori fulfilled.

Inspection of the equations that show the effect on the firm's expected value when investment or transfer prices are changed, reveals that the introduction of cross-border loss offset mitigates the effect of changes in either $\alpha$ or $p$ on tax liabilities - see equations (15) and (17) - while it boosts that effect in the case of a change in $q$ - see equation (16).

The intuition behind that conclusion is the following: assume that the corporate tax rate is lower in jurisdiction $i$ than in jurisdiction $j$, and, for simplicity, that there is no tax shield. In this case, the after-tax value of the firm increases with the fraction of the capital invested in the low-tax jurisdiction. The introduction of cross border loss offset mitigates, but does not

\footnotetext{
${ }^{19}$ Cross border offsetting makes the firm better off than carry forward offsetting in the same jurisdiction if, using equation (13) and assuming that offsetting can occur the year after,$$
\left[\left(\tau_{i}-\tau_{j}\right)-\frac{\tau_{j}-\tau_{i}}{1+r}\right] p(q-\alpha)-\left[\tau_{i}-\frac{\tau_{j}}{1+r}\right]\left(c+a_{j}\right)(1-\alpha)-\left[\tau_{j}-\frac{\tau_{i}}{1+r}\right]\left(c+a_{i}\right) \alpha<0
$$ 
reverse, that outcome; indeed, preserving enough tax base in the higher-tax jurisdiction allows the firm to benefit from a larger tax deduction in case the bad state of nature occurs in the lower taxing jurisdiction. The same reasoning holds for transfer pricing.

Unlike what is observed for the distribution of investment and the transfer price, the fraction of the sales in the lower tax rate jurisdiction is boosted up. Indeed sales is precisely the variable which is the source of uncertainty in this model. Since with cross-border loss offsetting, the risk is now shared, and thus insured, the multinational firm is likely to be more active in the risky activity.

We now examine a pure residence system, where only the tax rate in the residence jurisdiction matters. Expected tax liabilities become,

$$
E\left(T^{L O}\right)=E\left(T^{N L O}\right)-k \omega(1-\omega) \tau_{r}\left(c+a_{r}\right)
$$

so that cross border loss offset again reduces expected tax liabilities. Again, capital export neutrality holds while capital import neutrality further requires tax rate and tax base harmonization, $\tau_{r}, a_{r}=\tau, a \forall r$.

\subsection{Effect of loss offsetting on company responses to changing tax rates}

Regarding the location of active entities and of distribution centres and the determination of transfer prices, how does cross-border loss offsetting affect company responses to changing tax rates?

To answer the above question, we introduce a cost of changing decision function. ${ }^{20}$ Let $G(\alpha, q, p)$ be such a function and assume it is additively separable. In such a framework, the distribution of investment among the jurisdictions, for example, obeys the equality between the expected value of marginal tax liability and the marginal cost of moving, thus,

$$
\frac{d E\left(V^{L O}\right)}{d \alpha}=\frac{d G}{d \alpha}
$$

\footnotetext{
with $r$ a discounting rate; if tax rates are equal, a sufficient condition for that inequality to hold is $r>0$.

${ }^{20}$ This is a standard way of dealing with such topic since it is equivalent to the installation function usually introduced in investment model to guarantee an interior solution.
} 
As an example, if that cost function is quadratic, say $G(\alpha)=\left(\gamma_{\alpha} / 2\right)\left(\alpha-\alpha_{0}\right)^{2}$, then the following holds,

$$
0 \leq \alpha=\alpha_{0}+\frac{1}{\gamma_{\alpha}} \frac{d E\left(V^{L O}\right)}{d \alpha} \leq 1
$$

and check that,

$$
\frac{d \alpha}{d k}=\frac{1}{\gamma_{\alpha}} \frac{\partial^{2} E\left(V^{L O}\right)}{\partial k \partial \alpha}=\frac{\omega(1-\omega)}{\gamma_{\alpha}}\left[\left(\tau_{i}-\tau_{j}\right)(p-c)+\left(\tau_{i} a_{j}-\tau_{j} a_{i}\right)\right]
$$

Thus, the introduction of cross border loss offset drives down investment in the low taxing jurisdiction - suppose again $\tau_{i}<\tau_{j}-$, a result which confirms previous findings (see above).

The sensitivity of investment location, $\alpha$, to the corporate tax rate is,

$$
\frac{d \alpha}{d \tau_{i}}=-\frac{\frac{\partial^{2} E\left(V^{L O}\right)}{\partial \tau_{i} \partial \alpha}-\frac{\partial^{2} G}{\partial \tau_{i} \partial \alpha}}{\frac{\partial^{2} E\left(V^{L O}\right)}{\partial \alpha^{2}}-\frac{\partial^{2} G}{\partial \alpha^{2}}}
$$

which reduces to, assuming the quadratic moving cost function suggested above,

$$
\begin{aligned}
\frac{d \alpha}{d \tau_{i}} & =\frac{1}{\gamma_{\alpha}} \frac{\partial^{2} E\left(V^{L O}\right)}{\partial \tau_{i} \partial \alpha} \\
& =-\frac{\omega\left(p-c-a_{i}\right)-k \omega(1-\omega)\left(p-c-a_{j}\right)}{\gamma_{\alpha}} \\
& \equiv-\frac{\lambda_{i}}{\gamma_{\alpha}}
\end{aligned}
$$

Similar equations hold for distribution centres, $q$,

$$
\begin{aligned}
\frac{d q}{d \tau_{i}} & =\frac{1}{\gamma_{q}} \frac{\partial^{2} E\left(V^{L O}\right)}{\partial \tau_{i} \partial q} \\
& =\frac{-\omega(v-p)-k \omega(1-\omega) p}{\gamma_{q}}
\end{aligned}
$$

and for transfer prices, $p$,

$$
\begin{aligned}
\frac{d p}{d \tau_{i}} & =\frac{1}{\gamma_{p}} \frac{\partial^{2} E\left(V^{L O}\right)}{\partial \tau_{i} \partial \alpha} \\
& =\frac{\omega-k \omega(1-\omega)}{\gamma_{p}}(q-\alpha)
\end{aligned}
$$


The sensitivity of the distribution of investment and of the transfer price to the company tax rate is thus mitigated when losses can be compensated across borders. Unlike that, the response of sales is boosted up. This result is basically a consequence of the insurance device that cross border loss offsetting provides to the multinational firm.

Are we then allowed to say that cross border loss offset mitigates tax competition aiming to attract real investment location? Answering that question needs further evaluation - see below.

Finally note that,

$$
\begin{aligned}
\frac{d \alpha}{d \tau_{j}} & =\frac{1}{\gamma_{\alpha}} \frac{\partial^{2} E\left(V^{L O}\right)}{\partial \tau_{j} \partial \alpha} \\
& =\frac{\omega\left(p-c-a_{j}\right)-k \omega(1-\omega)\left(p-c-a_{i}\right)}{\gamma_{\alpha}} \\
& \equiv \frac{\lambda_{j}}{\gamma_{\alpha}}
\end{aligned}
$$

\subsection{Effect of cross border loss offset on interjurisdictional tax competition}

To complete that investigation, let us examine the consequence of cross border loss offset on tax competition within the area in which cross-border loss offsetting is allowed. Therefore, let us consider a simple model of interjurisdictional tax competition. Governments are assumed to maximize the jurisdiction's welfare, which increases with domestic investment and the amount of tax revenue available to finance public goods and services. Setting $u$ as the shadow cost of public funds and $E(B)$ as the expected tax base, and ignoring depreciation allowances, the government maximizes,

$$
\alpha+u_{i} \tau_{i} E\left(B_{i}\right)
$$

with respect to the domestic corporate tax rate. The first order condition with respect to a change in the tax rate is,

$$
\frac{d \alpha}{d \tau_{i}}+u_{i} E\left(B_{i}\right)+u_{i} \tau_{i} \frac{d E\left(B_{i}\right)}{d \tau_{i}}=0
$$


with

$$
\begin{aligned}
E\left(B_{i}\right) & =\omega\left[v q-p(q-\alpha)-\left(c+a_{i}\right) \alpha\right] \\
& +k \omega(1-\omega)\left[p(q-\alpha)-\left(c+a_{j}\right)(1-\alpha)\right]
\end{aligned}
$$

As a consequence the first order condition becomes,

$$
\begin{aligned}
& u_{i} \tau_{i}\left\{\omega[1-k(1-\omega)] p-\omega\left(c+a_{i}\right)+k \omega(1-\omega)\left(c+a_{j}\right)\right\} \frac{d \alpha}{d \tau_{i}} \\
& +u_{i} E\left(B_{i}\right)+\frac{d \alpha}{d \tau_{i}}=0
\end{aligned}
$$

with $\frac{d \alpha}{d \tau_{i}}$ given by equation (23).

Supposing that jurisdictions set their tax rates independently, the reaction function of jurisdiction $i$ is,

$$
\begin{aligned}
\frac{d \tau_{i}}{d \tau_{j}} & =-\frac{1}{2} \frac{\frac{d \alpha}{d \tau_{j}}}{\frac{d \alpha}{d \tau_{i}}}=\frac{1}{2} \frac{\lambda_{j}}{\lambda_{i}} \\
& =\frac{1}{2} \frac{\omega\left(p-c-a_{j}\right)-k \omega(1-\omega)\left(p-c-a_{i}\right)}{\omega\left(p-c-a_{i}\right)-k \omega(1-\omega)\left(p-c-a_{j}\right)}
\end{aligned}
$$

Inspection of equation (31) shows that the resulting Nash equilibrium is stable. Moreover it sets forth that cross border loss offsetting reduces both the value of the numerator and that of the denominator so that the effect of that mechanism on the reaction of tax authorities of jurisdiction $i$ to a change in the tax rate in jurisdiction $j$ is not as clear-cut as above. Indeed, the response of the reaction function to a change in $k$ is given by,

$$
\frac{d}{d k}\left(\frac{d \tau_{i}}{d \tau_{j}}\right) \propto \frac{\omega^{2}(1-\omega)}{2}\left[2(p-c)-\left(a_{i}+a_{j}\right)\right]\left(a_{i}-a_{j}\right)
$$

which shows that the relative generosity of tax shields plays a key role, as well as the value of the transfer price. 
To highlight the interpretation of that equation, suppose that tax shield is larger in jurisdiction $j$ than in jurisdiction $i$. In this case, the right hand side of equation (32) is negative for relatively large values of the transfer price, and introducing cross border loss compensation will moderate the reaction of jurisdiction $i$ in terms of tax rates.

The intuition is the following : if the government of jurisdiction $j$ reduces its corporate income tax rate, investment will flow from jurisdiction $i$ into jurisdiction $j$. However that outflow from $i$ will be refrained by the willingness of the multinational firm to keep enough tax base in jurisdiction $i$ to be able to match the possible loss in the other jurisdiction against that tax base. Knowing that, the government of jurisdiction $i$ will moderate its own tax cut in response to the tax cut of the other, competing, jurisdiction, if it is in such a position that the tax base on its territory is actually expected to be large. That phenomenon is more likely to occur when the tax shield is relatively small and the transfer price is relatively high - remember that the affiliate in the low-tax jurisdiction $i$ is a net buyer of the good within the multijurisdictional firm.

\section{Apportionment of a consolidated tax base}

So far, despite cross border loss offset in the computation of the tax bases, the tax bases are computed separately for each entity of the group, and each entity is required to pay its own tax liabilities. We now examine how company decisions are affected if the tax base is computed at the level of the group and then apportioned among the entities according to an agreed formula. In this case, each entity is responsible for paying its tax liabilities, but the tax base in each jurisdiction is determined according to the apportionment formula.

The fact that we jointly deal with consolidation and apportionment should not mask that those two features are per se independent. Indeed we can have apportionment without consolidation of losses, as in Canada, where consolidation is not allowed. ${ }^{21}$ This also can occur if the tax base is computed at the level of the group as simply the sum of entities' separately computed tax bases, even if it is done on the basis of a single set of rules. 
We will not discuss here the pros and cons of various formulae that may be used in an apportionment system. Authors such as Gordon and Wilson (1986), Goolsbee and Maydew (2000) and Gérard $(2002,2003)$ examine this issue. In this paper we will consider the impact of the apportionment system using a single criterion, the distribution of capital investment. ${ }^{22}$

Using equation (13), the expected consolidated tax base is,

$$
E(B)=\omega\left(v-c-a_{r}\right)-k \omega(1-\omega)\left(c+a_{r}\right)
$$

where $a_{r}$ stands for the common flow of depreciation allowances. This is exactly the same tax base as that used under the residence principle, as shown in equation (18). Assuming that $E(B)$ is apportioned according to the distribution of investment, expected tax liabilities in jurisdiction $i$ are then $\tau_{i} \alpha E(B)$, and similarly in the other jurisdiction. As a consequence, total expected tax liabilities of the group are,

$$
E(T)=\left[\alpha \tau_{i}+(1-\alpha) \tau_{j}\right]\left\{\omega\left(v-c-a_{r}\right)-k \omega(1-\omega)\left(c+a_{r}\right)\right\}
$$

and cross border loss offset reduces that amount.

\subsection{Effect on company decisions}

Let us re-examine two results obtained above. First, the impact of loss offsetting on the location of investment as given by equation (21), is shown below:

$$
\frac{d \alpha}{d k}=\frac{1}{\gamma_{\alpha}} \frac{\partial^{2} E(V)}{\partial k \partial \alpha}=\frac{\omega(1-\omega)}{\gamma_{\alpha}}\left(\tau_{i}-\tau_{j}\right)\left(c+a_{r}\right)
$$

Again, the introduction of cross border loss offset pushes up investment in the higher taxing jurisdiction, as also occurs under separate entity taxation and use of the source principle.

\footnotetext{
${ }^{21}$ In Canada, where consolidation is not permitted, Mintz and Smart (2003) observe that "since corporate groups are not required to consolidate income for tax purposes, a number of tax planning devices are essentially unrestricted for firms that incorporate separately in different provinces".

${ }^{22}$ For an alternative formulation of this analysis, see Eggert and Schjelderup (2003) and Nielsen, RaimondosMoller and Schjelderup (2003).
} 
Notice that the expression above vanishes under separate taxation and application of the residence principle.

The sensitivity of the location of investment, $\alpha$, to the corporate tax rate is,

$$
\begin{aligned}
\frac{d \alpha}{d \tau_{i}} & =\frac{1}{\gamma_{\alpha}} \frac{\partial^{2} E(V)}{\partial \tau_{i} \partial \alpha} \\
& =-\frac{\omega\left(v-c-a_{r}\right)-k \omega(1-\omega)\left(c+a_{r}\right)}{\gamma_{\alpha}}
\end{aligned}
$$

As in equation (23), consolidation mitigates tax-sensitivity of investment location.

If we compare the absolute values of expressions (23) and (36), for $k=0$, the case of no cross border loss offset, and $a_{r}=a_{i}$, then, since $v \geq p$, the sensitivity of the location of investment to a change in the corporate tax rate under apportionment is greater than or equal to that under separate taxation. Thus, per se, apportionment increases (more precisely, does not decrease) that sensitivity and is able to boost tax competition in comparison with the case of loss offsetting under separate accounting. In both cases however, cross border loss offset reduces that sensitivity.

The intuition behind that increased sensitivity is twofold. First, under apportionment, losses in the lower taxing jurisdiction, when offset across border, are not turned into a tax reduction at the rate applicable in the higher taxing jurisdiction, but at a rate which is an average between the rates prevailing in both jurisdictions. And, second, the overall profit of the multinational firm will be partially taxed at the rate of the lower taxing jurisdiction, even if the entity in that jurisdiction faces losses and even if there is no loss offset, which is a further argument in favour of locating in the lower taxing jurisdiction.

\subsection{Effect on interjurisdictional tax competition}

We rewrite the social welfare function that the government of jurisdiction $i$ maximises as,

$$
\alpha+u_{i} \tau_{i} \alpha E(B)
$$

The first order condition of that maximisation is, 


$$
\frac{d \alpha}{d \tau_{i}}\left[1+u_{i} \tau_{i} E(B)\right]+u_{i} \alpha E(B)=0
$$

while the reaction function becomes, given equation (36),

$$
\frac{d \tau_{i}}{d \tau_{j}}=\frac{1}{2}
$$

which is independent of $k$. We can compare that latter equation with its counterpart under separate taxation, (31), showing that formulary apportionment per se boosts tax competition in a jurisdiction where, before the tax reform, tax shield was relatively low.

Let us add that under apportionment, jurisdictions compete not only to have investment because they increase employment and government revenue if the activity of the firm in the jurisdiction generates profits, but also because the jurisdiction receives revenue even if the activity in the jurisdiction is not profitable, provided that the multinational firm is profitable overall. In some sense, apportionment provides the government of a jurisdiction with an insurance or risk-sharing mechanism against revenue losses in case of a bad state of nature (i.e., losses) on its territory. ${ }^{23}$ As a consequence, apportionment can make a risk averse government better off.

\section{Conclusion}

This paper has investigated the effect of the introduction of cross border loss offset and apportionment of the tax base, on both the behaviour of a multijurisdictional firm in terms of allocation of investment and distribution centres, and of transfer pricing strategy, and on the behaviour of governments engaged in interjurisdictional competition. Though motivated by the reforms suggested by the European Commission in 2001 and 2002, the lessons of the paper also apply to other situations where additional possibilities of risk sharing among geographically distributed entities of a given firm are introduced. In reference to the EU Commission proposed approaches, we have compared the impact of cross-border loss offset and consolidation under two tax systems, separate entity taxation and formulary apportionment of a consolidated tax base.

\footnotetext{
${ }^{23}$ As pointed out by Michael Smart, formulary apportionment can also be regarded as a redistribution or equalisation device among jurisdictions.
} 
We have shown that cross border loss offset mitigates the reaction of the firms in terms of investment location and transfer pricing policy, and affects the reaction of the governments to tax changes by other jurisdictions.

Regarding firms, the intuition behind that result is the following: assume that the corporate tax rate is lower in jurisdiction $i$ than in jurisdiction $j$, and, for simplicity, that there is no tax shield. Then, the after-tax value of the firm increases with the fraction of the capital invested in the low-tax jurisdiction. However, the introduction of cross border loss offset mitigates, but does not reverse, that situation. Indeed, preserving enough investment in the other jurisdiction, that with the higher tax rate, allows the firm to benefit from a larger deductibility against the corporate tax base in that jurisdiction, in case losses occur in the lower taxing jurisdiction. The same reasoning holds for transfer pricing.

For governments, the intuition can be similar: if the government of jurisdiction $j$ reduces its corporate income tax rate, there will be an outflow of investment from jurisdiction $i$ to jurisdiction $j$. However, that outflow will be refrained by the willingness of the multinational firm to keep enough tax base in jurisdiction $i$ in order to be able to match the possible loss in the other jurisdiction against that tax base. Knowing that, the government of jurisdiction $i$ will moderate its own tax cut in response to the tax cut of its competitor. However that behaviour will be reversed if a relatively high level of tax shield on its own territory reduces the tax base in that jurisdiction.

Furthermore, we show that apportionment, per se, boosts the sensitivity of firms' behaviour to changes in tax rates, and thus, possibly, boosts tax competition.

The intuition behind that increased sensitivity and behind the boosting of tax competition, is twofold. First, under apportionment, losses in the lower taxing jurisdiction, when offset across border, are not turned into a tax reduction at the rate at work in the higher taxing jurisdiction, but at a rate which is an average between those prevailing in both jurisdictions. And second, the overall profit of the multinational firm will be partially taxed at the rate of the lower taxing jurisdiction, even if the entity in that jurisdiction faces losses and even if there is no loss offset, which is a further argument to locate in the lower taxing jurisdiction. 
In addition, under apportionment, jurisdictions compete not only for investment as a jobcreating device and for company tax revenue if the firm's activity in the jurisdiction is profitable, but also because they generate revenue even if the activity in the jurisdiction is not profitable, provided the multinational firm is profitable over all the other jurisdictions of the apportionment area. In this sense, apportionment provides the government of a jurisdiction with a insurance or risk-sharing mechanism against revenue losses in case of a bad state of the nature on its territory.

To complete the paper, let us mention that next steps in that line of research should include a more elaborated comparison between cross border and carry forward loss offsetting on the one hand and a more general way to cope with uncertainty on the other hand. Indications for those steps are already suggested in the present text.

July 2003

\section{References}

Auerbach, A., 1979, "Wealth maximization and the cost of capital", Quarterly Journal of Economics, 93, 433-446.

Bradford, D., 1981, "The incidence and allocation effects of a tax on corporate distributions", Journal of Public Economics, 15, 1-22.

Diamond, P. and J. Stiglitz, 1974, "Increases in risk and in risk aversion", Journal of Economic Theory, 8, 337-360.

Eeckhoudt, L. and P. Hansen, 1982, "Uncertainty and partial loss offset provision", Economics Letters, 9, 31-35.

Eeckhoudt, L., C. Gollier and H. Schlesinger, 1997, "The no-loss offset provision and the attitude towards risk of a risk-neutral firm”, Journal of Public Economics, 65, 207-217.

Eggert, W. and G. Schjelderup, 2003, "Symmetric tax competition under formula apportionment", Journal of Public Economic Theory, 5 (2), 437-444.

European Commission, 2001, Towards an Internal Market without tax obstacles, COM (2001) 582 final, 23 October 2001.

European Commission, 2002, Company taxation in the internal market, Commission staff working paper, Office of Official Publications for the European Communities: Luxembourg (Originally published as SEC(2001) 1681, 23 October 2001).

European Commission, 2003, 'The application of International Accounting Standards (IAS) in 2005 and the implications for the introduction of a consolidated tax base for companies' EU-wide activities," Consultation Document, February 2003. 
European Taxation, 2002, Special Issue. Company Tax Reform in the European Union: Targeted Measures and Comprehensive Proposals, Official Journal of the Confédération Fiscale Européenne, $42(8)$.

Gérard, M., 2002, "Neutralities and Non-Neutralities in International Corporate Taxation: An Evaluation of Possible and Recent Moves", Ifo-Studiën, 48 (4), 533-554.

Gérard, M., 2003, "L'imposition des entreprises multinationales en Europe, à propos d'un rapport de la Commission européenne", Revue Economique, 58 (4), 489-498.

Gordon, R. and J. Wilson (1986), «An examination of multijurisdictional corporate income taxation under formula apportionment, » Econometrica, 54 (6), 1357-1373.

Goolsbee, A. and E. Maydew (2000), "Coveting thy neighbor's manufacturing: the dilemma of state income apportionment", Journal of Public Economics, 75, 125-143.

Hellerstein, J., 1993, "Federal Income Taxation of Multinationals: Replacement of Separate Accounting with Formulary Apportionment", Tax Notes 60 (10), 1131-1145.

McDaniel, P.R., 1994, "Formulary Taxation in the North American Free Trade Zone", Tax Law Review, 49 (4), 691-744.

Mintz, J. and M. Smart, 2003, "Income shifting, investment, and tax competition: Theory and evidence from provincial taxation in Canada", Journal of Public Economics, forthcoming.

Mossin, J., 1968, “Taxation and risk-taking: an expected utility approach”, Economica, 35, 74-82.

Musgrave, P.B., 2000, "Interjurisdictional Equity in Company Taxation: Principles and Applications to the European Union", in: S. Cnossen (ed.), Taxing Capital Income in the European Union. Issues and Options for Reform, Oxford: Oxford University Press, 46-77.

Myles, G., 1995, Public Economics, Cambridge: Cambridge University Press.

Nielsen, S., P. Raimondos-Moller and G. Schjelderup, 2003, "Tax spillovers under separate accounting and formula apportionment", Economic Policy Research Union paper 01-07, Copenhagen Business School.

Sandmo, A., 1977, "Portfolio theory, asset demand and taxation: comparative statics with many assets", Review of Economic Studies, 44, 369-379.

Stiglitz, J., 1969, "The effects of income, wealth, and capital gains taxation on risk-taking", Quarterly Journal of Economics, 83, 262-283.

Union of Industrial and Employers' Confederations of Europe (UNICE), 2000, Memorandum on cross-border company taxation obstacles in the single market, 3 April 2000.

Weiner, J. 1999, "Using the Experience in the U.S. States to Evaluate Issues in Implementing Formula Apportionment at the International Level," OTA Paper 83, Office of Tax Analysis, U.S. Department of the Treasury: Washington, D.C.

Weiner, J., 2001a, "The European Union and Formula Apportionment: Caveat Emptor", European Taxation, 41 (10), 380-388. 
Weiner, J., 2001b, “EU Commission Proposes Strategy for Consolidating Corporate Tax Bases," Tax Notes International 24 (5), 515.519.

Weiner, J., 2002a, "Would Introducing Formula Apportionment in the European Union Be a Dream Come True or the EU's Worst Nightmare?", Ifo-Studiën, 48 (4), 519-532.

Weiner, J., 2002b, "EU Commission, Member States Commit to EU-Wide Company Taxation, Formula Apportionment," Tax Notes International 25, (5) (6 May 2002), 515-520

Westberg, B., 2002, "Consolidated Corporate Tax Bases for EU-Wide Activities: Evaluation of Four Proposals Presented by the European Commission," European Taxation 42 (8), 322-330. 


\title{
CESifo Working Paper Series
}

\author{
(for full list see www.cesifo.de)
}

938 Sören Blomquist and Vidar Christiansen, Is there a Case for Public Provision of Private Goods if Preferences are Heterogeneous? An Example with Day Care, May 2003

939 Hendrik Jürges, Kerstin Schneider, and Felix Büchel, The Effect of Central Exit Examinations on Student Achievement: Quasi-experimental Evidence from TIMSS Germany, May 2003

940 Samuel Bentolila and Juan F. Jimeno, Spanish Unemployment: The End of the Wild Ride?, May 2003

941 Thorsten Bayindir-Upmann and Anke Gerber, The Kalai-Smorodinsky Solution in Labor-Market Negotiations, May 2003

942 Ronnie Schöb, Workfare and Trade Unions: Labor Market Repercussions of Welfare Reform, May 2003

943 Marko Köthenbürger, Tax Competition in a Fiscal Union with Decentralized Leadership, May 2003

944 Albert Banal-Estañol, Inés Macho-Stadler, and Jo Seldeslachts, Mergers, Investment Decisions and Internal Organisation, May 2003

945 Kaniska Dam and David Pérez-Castrillo, The Principal-Agent Matching Market, May 2003

946 Ronnie Schöb, The Double Dividend Hypothesis of Environmental Taxes: A Survey, May 2003

947 Erkki Koskela and Mikko Puhakka, Stabilizing Competitive Cycles with Distortionary Taxation, May 2003

948 Steffen Huck and Kai A. Konrad, Strategic Trade Policy and Merger Profitability, May 2003

949 Frederick van der Ploeg, Beyond the Dogma of the Fixed Book Price Agreement, May 2003

950 Thomas Eichner and Rüdiger Pethig, A Microfoundation of Predator-Prey Dynamics, May 2003

951 Burkhard Heer and Bernd Süssmuth, Cold Progression and its Effects on Income Distribution, May 2003 
952 Yu-Fu Chen and Michael Funke, Labour Demand in Germany: An Assessment of NonWage Labour Costs, May 2003

953 Hans Gersbach and Hans Haller, Competitive Markets, Collective Decisions and Group Formation, May 2003

954 Armin Falk, Urs Fischbacher, and Simon Gächter, Living in Two Neighborhoods Social Interactions in the LAB, May 2003

955 Margarita Katsimi, Training, Job Security and Incentive Wages, May 2003

956 Clemens Fuest, Bernd Huber, and Jack Mintz, Capital Mobility and Tax Competition: A Survey, May 2003

957 Edward Castronova, The Price of 'Man' and 'Woman': A Hedonic Pricing Model of Avatar Attributes in a Synthetic World, June 2003

958 Laura Bottazzi and Marco Da Rin, Financing Entrepreneurial Firms in Europe: Facts, Issues, and Research Agenda, June 2003

959 Bruno S. Frey and Matthias Benz, Being Independent is a Great Thing: Subjective Evaluations of Self-Employment and Hierarchy, June 2003

960 Aaron Tornell and Frank Westermann, Credit Market Imperfections in Middle Income Countries, June 2003

961 Hans-Werner Sinn and Wolfgang Ochel, Social Union, Convergence and Migration, June 2003

962 Michael P. Devereux, Measuring Taxes on Income from Capital, June 2003

963 Jakob de Haan, Jan-Egbert Sturm and Bjørn Volkerink, How to Measure the Tax Burden on Labour at the Macro-Level?, June 2003

964 Harry Grubert, The Tax Burden on Cross-Border Investment: Company Strategies and Country Responses, June 2003

965 Kirk A. Collins and James B. Davies, Measuring Effective Tax Rates on Human Capital: Methodology and an Application to Canada, June 2003

966 W. Steven Clark, Using Micro-Data to Assess Average Tax Rates, June 2003

967 Christopher Heady, The 'Taxing Wages' Approach to Measuring the Tax Burden on Labour, June 2003

968 Michael P. Devereux and Alexander Klemm, Measuring Taxes on Income from Capital: Evidence from the UK, June 2003

969 Bernhard Eckwert and Itzhak Zilcha, The Effect of Better Information on Income Inequality, June 2003 
970 Hartmut Egger and Josef Falkinger, The Role of Public Infrastructure for Firm Location and International Outsourcing, June 2003

971 Dag Morten Dalen and Trond E. Olsen, Regulatory Competition and Multi-national Banking, June 2003

972 Matthias Wrede, Tax Deductibility of Commuting Expenses and Residential Land Use with more than one Center, June 2003

973 Alessandro Cigno and Annalisa Luporini, Scholarships or Student Loans? Subsidizing Higher Education in the Presence of Moral Hazard, June 2003

974 Chang Woon Nam, Andrea Gebauer and Rüdiger Parsche, Is the Completion of EU Single Market Hindered by VAT Evasion?, June 2003

975 Michael Braulke and Giacomo Corneo, Capital Taxation May Survive in Open Economies, July 2003

976 Assar Lindbeck, An Essay on Welfare State Dynamics, July 2003

977 Henrik Jordahl and Luca Micheletto, Optimal Utilitarian Taxation and Horizontal Equity, July 2003

978 Martin D. D. Evans and Richard K. Lyons, Are Different-Currency Assets Imperfect Substitutes?, July 2003

979 Thorsten Bayindir-Upmann and Frank Stähler, Market Entry Regulation and International Competition, July 2003

980 Vivek Ghosal, Firm and Establishment Volatility: The Role of Sunk Costs, Profit Uncertainty and Technological Change, July 2003

981 Christopher A. Pissarides, Unemployment in Britain: A European Success Story, July 2003

982 Wolfgang Buchholz, Richard Cornes, and Wolfgang Peters, On the Frequency of Interior Cournot-Nash Equilibria in a Public Good Economy, July 2003

983 Syed M. Ahsan and Panagiotis Tsigaris, Choice of Tax Base Revisited: Cash Flow vs. Prepayment Approaches to Consumption Taxation, July 2003

984 Campbell Leith and Jim Malley, A Sectoral Analysis of Price-Setting Behavior in US Manufacturing Industries, July 2003

985 Hyun Park and Apostolis Philippopoulos, Choosing Club Membership under Tax Competition and Free Riding, July 2003

986 Federico Etro, Globalization and Political Geography, July 2003

987 Dan Ariely, Axel Ockenfels and Alvin E. Roth, An Experimental Analysis of Ending Rules in Internet Auctions, July 2003 
988 Paola Conconi and Carlo Perroni, Self-Enforcing International Agreements and Domestic Policy Credibility, July 2003

989 Charles B. Blankart and Christian Kirchner, The Deadlock of the EU Budget: An Economic Analysis of Ways In and Ways Out, July 2003

990 M. Hasham Pesaran and Allan Timmermann, Small Sample Properties of Forecasts from Autoregressive Models under Structural Breaks, July 2003

991 Hyun Park, Apostolis Philippopoulos and Vangelis Vassilatos, On the Optimal Size of Public Sector under Rent-Seeking competition from State Coffers, July 2003

992 Axel Ockenfels and Alvin E. Roth, Late and Multiple Bidding in Second Price Internet Auctions: Theory and Evidence Concerning Different Rules for Ending an Auction, July 2003

993 Pierre Salmon, The Assignment of Powers in an Open-ended European Union, July 2003

994 Louis N. Christofides and Chen Peng, Contract Duration and Indexation in a Period of Real and Nominal Uncertainty, July 2003

995 M. Hashem Pesaran, Til Schuermann, Björn-Jakob Treutler, and Scott M. Weiner, Macroeconomic Dynamics and Credit Risk: A Global Perspective, July 2003

996 Massimo Bordignon and Sandro Brusco, On Enhanced Cooperation, July 2003

997 David F. Bradford, Addressing the Transfer-Pricing Problem in an Origin-Basis X Tax, July 2003

998 Daniel Gros, Who Needs Foreign Banks?, July 2003

999 Wolfram Merzyn and Heinrich W. Ursprung, Voter Support for Privatizing Education: Evidence on Self-Interest and Ideology, July 2003

1000 Jo Thori Lind, Fractionalization and the Size of Government, July 2003

1001 Daniel Friedman and Donald Wittman, Litigation with Symmetric Bargaining and TwoSided Incomplete Information, July 2003

1002 Matthew Clarke and Sardar M. N. Islam, Health Adjusted GDP (HAGDP) Measures of the Relationship Between Economic Growth, Health Outcomes and Social Welfare, July 2003

1003 Volker Grossmann, Contest for Attention in a Quality-Ladder Model of Endogenous Growth, August 2003

1004 Marcel Gérard and Joan Martens Weiner, Cross-Border Loss Offset and Formulary Apportionment: How do they affect multijurisdictional firm investment spending and interjurisdictional tax competition?, August 2003 